Number 6

\title{
UJI AKTIVITAS ANTIBAKTERI REBUSAN DAUN SIRIH (Piper betle Linn) TERHADAP BAKTERI Streptococcus pyogenes
}

\author{
Sevita Amanda ${ }^{1}$, Nyoman Mastra ${ }^{2}$, I Gede Sudarmanto ${ }^{3}$ \\ Jurusan Analis Kesehatan Poltekkes Denpasar ${ }^{1,2,3}$ \\ nyoman_mastra@yahoo.co.id
}

\begin{abstract}
:
Background: Infection is a disease caused by pathogenic microbes and is very dynamic. ISPA is defined as an acute respiratory disease caused by infectious agents that were transmitted from human to human. One of the microbes that caused ISPA is Streptococcus pyogenes, which is a gram-positive bacteria and belongs to Streptococcus sp. $\beta$-hemolytic class A. Nowadays, many people are begin to use natural materials to deal with microbial infections. One of them is the betel leaf (Piper betle Linn.) Which has antibacterial and antibiotic components for the treatment of respiratory problems, and bacterial infectious diseases.

Purpose: This research was conducted with the aim to know the antibacterial activity of betel leaves (Piper betle Linn) decoction against Streptococcus pyogenes bacteria. Methods: This research used true experimental design with Posttest Only Control Design, and data analysis with One Way Anova and Least Significant Deference (LSD). Betel leaves decoction water is made in concentrations of 20\%, 40\%, $60 \%, 80 \%$, and 100\%, then tested on Streptococcus pyogenes bacteria with two replicates and four repetitions.

Result: From a total of 40 data obtained, the mean diameter of the inhibitory zone at each concentrations is $20 \% 0 \mathrm{~mm}, 40 \% 12.9 \mathrm{~mm}, 60 \% 22.7 \mathrm{~mm}, 80 \% 25.5 \mathrm{~mm}$, and $100 \% 30 \mathrm{~mm}$.

Conclution: Betel leaves decoction water is able to inhibit the growth of Streptococcus pyogenes with significant difference of drag zone diameter at each concentration.
\end{abstract}

Keywords: Antibacterial, Betel Leaves, Streptococcus pyogenes

\section{PENDAHULUAN}

Infeksi adalah penyakit yang disebabkan oleh mikroba patogen dan bersifat sangat dinamis. ISPA didefinisikan sebagai penyakit saluran pernapasan akut yang disebabkan oleh agen infeksius yang ditularkan dari manusia ke manusia. Salah satu mikroba penyebab ISPA adalah bakteri Streptococcus pyogenes, yang merupakan bakteri gram positif dan termasuk dalam jenis Streptococcus $s p$. $\beta$-hemolytic golongan A. Dewasa ini, banyak masyarakat yang mulai memanfaatkan bahan alam untuk menangani infeksi akibat mikroba. Salah satu bahan alam yang dapat dimanfaatkan adalah daun sirih (Piper betle Linn.). daun sirih (Piper betle Linn) memiliki komponen antibakteri dan antibiotik untuk pengobatan masalah pernapasan, dan penyakit akibat infeksi bakteri. Penelitian ini dilakukan dengan tujuan untuk mengetahui aktivitas antibakteri rebusan daun sirih (Piper betle Linn) terhadap bakteri Streptococcus pyogenes. 
Streptococcus terdiri dari kokus yang berdiameter $0,5-1 \mu \mathrm{m}$. Dalam bentuk rantai yang khas, kokus agak memanjang pada arah sumbu rantai ${ }^{1}$. Streptococcus pyogenes sangat menular dan dapat menyebabkan penyakit pada individu dari semua umur yang tidak memiliki kekebalan spesifik jenis ${ }^{2}$.

Uji fitokimia ekstrak dari daun sirih yang dilakukan oleh ${ }^{3}$ menunjukkan adanya steroid, diterpenes, tanin, glikosida kardial, flavonoid, saponin, fenol, koumarin dan alkaloid. Daun sirih mengandung minyak atsiri yang terdiri dari betlephenol, kavikol, seskuiterpe, hidrokdikavikol, cavibetol, estragol, eugenol dan karvakol. Daun sirih juga memiliki kandungan enzim diastase, gula dan tanin. Kandungan kavikol dan betlephenol menyebabkan daun sirih memiliki aroma dan rasa yang khas. Keseluruhan kandungan yang ada dalam daun sirih itulah, maka sirih berkhasiat sebagai antioksidan dan fungisida ${ }^{4}$.

Penelitian terkait pengaruh air rebusan daun sirih terhadap bakteri Streptococcus sp., telah dilakukan oleh Sugianti $^{5}$ yang menguji pada bakteri Streptococcus mutans dengan air rebusan daun sirih. Hasil yang didapat pada penelitian tersebut adalah diameter zona hambat berukuran $0 \mathrm{~mm}$ pada konsentrasi $20 \%, \quad 6,67 \mathrm{~mm}$ pada konsentrasi 40\%, 7,33 $\mathrm{mm}$ pada konsentrasi $60 \%, 8 \mathrm{~mm}$ pada konsentrasi $80 \%$, dan $7,67 \mathrm{~mm}$ pada konsentrasi $100 \%$.

\section{METODE}

Penelitian ini menggunakan jenis penelitiantrue experimental designdengan Posttest Only Control Design. Dalam penelitian ini, digunakan metode difusi cara kirby bauer untuk mengetahui ada atau tidak adanya zona hambat terhadap bakteri Streptococcus pyogenes, dan dilaksanakan di Laboratorium Bakteriologi Politeknik Kesehatan Denpasar Jurusan Analis Kesehatan.

Tahap penelitian ini dimulai dengan menginokulasikan bakteri Streptococcus pyogenes pada media Mueller Hinton Agar (MHA), kemudian masing-masing cakram disk yang mengandung berbagai konsentrasi air rebusan daun sirih $(20 \%, 40 \%, 60 \%$, $80 \%$, dan 100\%), kontrol positif (Amoxicillin) dan kontrol negatif (aquadest steril) ditempelkan pada permukaan media. Setelah itu, diinkubasi pada suhu $37^{\circ} \mathrm{C}$ selama 24 jam. Zona hambat yang terbentuk berupa zona bening di sekitar cakram disk 
dihitung dan dinyatakan dalam $\mathrm{mm}$ (milimeter).

\section{HASIL DAN PEMBAHASAN}

\section{Hasil}

Data yang telah diperoleh kemudian dianalisis menggunakan uji statistik. Untuk mengetahui ada atau tidaknya perbedaan zona hambat pertumbuhan Streptococcus pyogenes pada berbagai konsentrasi air rebusan daun sirih, terlebih dahulu perlu diperlukan uji Kolmogorov Smirnov (KS) untuk mengetahui apakah data berdistribusi normal atau tidak. Sehingga dapat menentukan jenis uji yang sesuai. Setelah dilakukan uji normalitas, diperoleh nilai Asymp. Sig.sebesar 0,079. Hal tersebut menunjukkan nilai lebih besar dari sig $\alpha(0,05)$ atau Asymp. Sig. $(0,079)>\alpha(0,05)$.

Uji dilanjutkan dengan uji One Way Anovauntuk mengetahui adanya perbedaan diameter zona hambat terhadap pertumbuhan bakteri Streptococcus pyogenes.
Setelah dilakukan uji One Way Anova, diperoleh nilai Sig. $(0,000)$ yang menunjukkan nilai lebih kecil dari $\alpha$ $(0,05)$ atau Sig. $(0,000)<\alpha(0,05)$. Selanjutnya, untuk mengetahui perbedaan diameter zona hambat dari berbagai konsentrasi rebusan daun sirih terhadap pertumbuhan Streptococcus pyogenes, digunakan uji Least Significant Deference (LSD). Pada seluruh perbandingan masing-masing konsentrasi, menunjukkan nilai Sig. yang sama yaitu 0,000 .

\section{Pembahasan}

a. Diameter zona hambat kontrol dan Amoxicillin terhadap pertumbuhan Streptococcus pyogenes

Hasil uji pada kontrol negatif tidak menunjukkan adanya zona hambat, sedangkan pada kontrol positif dengan Amoxicillin menunjukkan adanya zona hambat dengan rerata dari seluruh replikasi yaitu $35,2 \mathrm{~mm}$. 
Sevita Amanda, dkk., Uji Aktivitas Antibakteri Rebusan Daun Sirih (Piper Betle Linn) Terhadap Bakteri Streptococcus Pyogenes

Tabel 1. Data Hasil Uji Aktivitas Antibakteri Rebusan Daun Sirih (Piper betle Linn) Terhadap Bakteri Streptococcus pyogenes

zona hambat dengan rerata dari seluruh

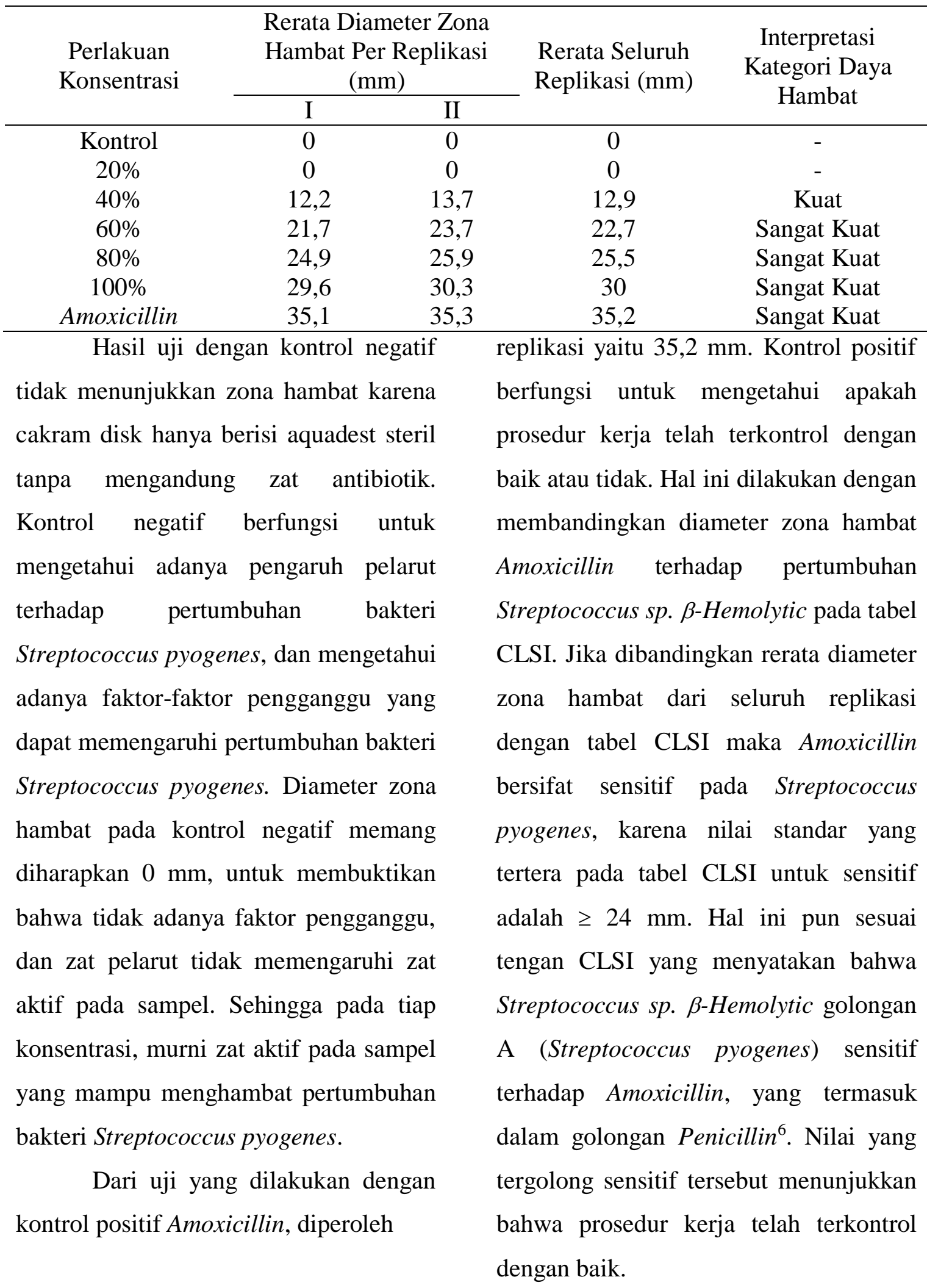


b. Diameter zona hambat berbagai konsentrasi air rebusan daun sirih terhadap pertumbuhan Streptococcus pyogenes

Dari hasil pengukuran diameter zona hambat pada konsentrasi $20 \%$ diperoleh rerata diameter zona hambat dari seluruh replikasi yaitu $0 \mathrm{~mm}$, sedangkan pada konsentrasi $40 \%$ mulai terbentuk zona bening disekitar cakram dengan rerata berukuran diameter 12,9 mm. Diameter zona hambat pada konsentrasi $60 \%$ dari rerata seluruh replikasi adalah 22,7 $\mathrm{mm}$. Pada konsentrasi $80 \%$ didapat rerata diameter zona hambat dari seluruh replikasi yaitu $25,5 \mathrm{~mm}$, dan pada konsentrasi $100 \%$ rerata diameter zona hambat yang terbentuk adalah $30 \mathrm{~mm}$.

Dari hasil yang didapat, kemudian dibandingkan dengan kategori daya hambat menurut Riska F dan Puguh S (2014) dalamYanti \& Mitika ${ }^{7}$. Pada konsentrasi $20 \%$, air rebusan daun sirih tidak mampu menghambat pertumbuhan bakteri Streptococcus pyogenes, karena sama sekali tidak tampak zona bening di sekitar cakram disk. Hal tersebut disebabkan oleh zat aktif daun sirih dalam pengenceran $20 \%$ masih terlalu sedikit untuk mampu menghambat pertumbuhan bakteri Streptococcus pyogenes.

Dari rerata diameter zona hambat seluruh replikasi, air rebusan daun sirih konsentrasi $40 \%$ menunjukkan nilai yang tergolong kategori kuat dalam menghambat pertumbuhan bakteri Streptococcus pyogenes, karena termasuk dalam rentang kuat yaitu 11-20 mm. Sedangkan pada konsentrasi $60 \%$, $80 \%$, dan $100 \%$, ketiganya tergolong kategori sangat kuat dalam menghambat pertumbuhan bakteri Streptococcus pyogenes, dimana diameter zona hambat lebih dari $21 \mathrm{~mm}(\geq 21 \mathrm{~mm})$.

Dilihat dari rerata diameter zona hambat pada berbagai konsentrasi air rebusan daun sirih $(20 \%, 40 \%, 60 \%$, $80 \%$, dan 100\%), semakin besar konsentrasi air rebusan yang digunakan maka semakin besar ukuran diameter zona hambat pertumbuhan bakteri Streptococcus pyogenes. Hal ini menunjukkan bahwa, diameter zona hambat berbanding lurus dengan besarnya konsentrasi air rebusan daun sirih. Semakin besar diameter zona hambat yang terbentuk disebabkan oleh jumlah zat aktif pada berbagai konsentrasi air rebusan daun sirih semakin besar. Pada konsentrasi 20\%, sebagian besar terdiri dari pengencer 
(aquadest steril) yang tidak memiliki kemampuan dalam menghambat pertumbuhan bakteri Streptococcus pyogenes. Semakin besar konsentrasi, maka semakin besar zat aktif yang terlarut, karena semakin sedikit pula pengencer yang digunakan. Sehingga larutan dengan konsentrasi yang lebih tinggi akan memiliki zat aktif yang lebih pekat.

Berdasarkan hasil penelitian yang dilakukan oleh ${ }^{8}$, ekstrak air daun sirih hijau positif mengandung metabolit sekunder berupa flavonoid, tanin, dan fenol.Flavonoid yang mudah larut dalam air mampu mendenaturasi protein dan merusak membran sel bakteri dengan cara melarutkan lemak yang terdapat pada dinding sel. Senyawa ini mampu melakukan migrasi dari fase cair ke fase lemak. Terjadinya kerusakan pada membran sel mengakibatkan terhambatnya aktivitas dan biosintesa enzim-enzim spesifik yang diperlukan dalam reaksi metabolisme dan kondisi ini yang pada akhirnya menyebabkan kematian pada bakteri ${ }^{9}$.

Tanin dapat larut dalam air, dan kelarutannya akan meningkat apabila dilarutkan dalam suhu tinggi. Tanin mampu mengkerutkan dinding sel atau membran sel sehingga mengganggu permeabilitas, sel tidak dapat melakukan aktivitas hidup sehingga pertumbuhannya terhambat atau bahkan mati $^{10}$. Fenol merupakan senyawa toksik yang menyebabkan protein sel pada bakteri mengalami denaturasi sehingga protein tidak dapat melakukan fungsinya ${ }^{11}$. Denganterdenaturasinya protein sel maka semua aktivitas metabolisme seldikatalisis oleh enzim sehingga mikroba atau jamur tidak dapat bertahan hidup ${ }^{12}$.

\section{SIMPULAN DAN SARAN}

Berdasarkan penelitian yang telah dilakukan, dapat disimpulkan bahwa air rebusan daun sirih mampu menghambat pertumbuhan bakteri Streptococcus pyogenes mulai dari konsentrasi $40 \%$ dengan katerogi daya hambat kuat, serta pada konsentrasi $60 \%, 80 \%$, dan $100 \%$ dapat menghambat bakteri Streptococcus pyogenes dengan katergori sangat kuat. Dari uji yang telah dilakukan, dapat diketahui bahwa, diameter zona hambat yang terbentuk pada masing-masing konsentrasi memiliki perbedaan yang bermakna.

Saran yang dapat diberikan dari penelitian ini adalah bagi peneliti selanjutnya diharapkan untuk mengembangkan penelitian ini pada 
jenis bakteri yang berbeda, atau dengan metode berbeda.Bagi masyarakat diharapkan untuk lebih sering memanfaatkan rebusan daun sirih dengan konsentrasi paling efektif yaitu 100\%, dalam kehidupan sehari-hari sebagai obat tradisional dengan cara diminum.Bagi pemerintah diharapkan untuk meningkatkan peran dalam pemanfaatan bahan alam, khususnya daun sirih sebagai obat tradisional, dengan meningkatkan sektor obat herbal untuk meningkatkan kesehatan masyarakat.

\section{DAFTAR PUSTAKA}

1. Asriadi. Uji Sensitivitas Beberapa Antibiotika Terhadap Bakteri Penyebab Infeksi Saluran Pernapasan Atas (Ispa) Di Rsud Syech Yusuf Kab. Gowa. 2012. http://repositori.uinalauddin.ac.id/3203/1/ASRIADI.pdf.

2. Nizet V, Arnold JC. Streptococcus Pyogenes (Group A Streptococcus). Fourth Edi. Elsevier Inc.; 2012. doi:10.1016/B978-1-4377-27029.00120-3.

3. Patil RS, Harale PM, Shivangekar KV, Kumbhar PP, Desai RR. Phytochemical potential and in vitro antimicrobial activity of Piper betle Linn. leaf extracts. $J$ Chem Pharm Res. 2015;7(5):1095-1101. http://www.jocpr.com/articles/phytoc hemical-potential-and-in-vitroantimicrobial-activity-of-piper-betlelinn-leaf-extracts.pdf.

4. Akbar R. Aneka Tanaman Apotek
Hidup Di Sekitar Kita. 1st ed. (Cahyono F, ed.). Jakarta: One Book; 2015.

5. Sugianti NKM. Pengaruh Air Rebusan Daun Sirih Dalam Berbagai Konsentrasi Terhadap Daya Hambat Pertumbuhan Bakteri Streptococcus mutans Secara In Vitro. 2015.

6. CLSI. Performance Standards for Antimicrobial Susceptibility Testing. 27th ed. (Tertel ML, Christopher JP, Martin L, Russell MA, eds.). Wayne: Clinical and Laboratory Standards Institute; 2017.

7. Yanti YN, Mitika S. Uji Efektivitas Antibakteri Ekstrak Etanol Daun Sambiloto ( Andrographis paniculata Nees ) Terhadap Bakteri Staphylococus aureus. J Ilm Ibnu Sina. 2017;2(1):158-168.

8. Chakraborty D, Shah B. Antimicrobial , Anti - Oxidative and Anti - Hemolytic Activity of Piper Betel Leaf Extracts. Int J Pharm Pharm Sci. 2011;3(3):192-199.

9. Rohyani IS, Aryanti E, Suripto. Kandungan fitokimia beberapa jenis tumbuhan lokal yang sering dimanfaatkan sebagai bahan baku obat. 2015;1(April):388-391. doi:10.13057/psnmbi/m010237.

10. Mariyatin H, Widyowati E, Lestari S. Efektivitas antibakteri ekstrak daun sirih merah ( Piper crocatum ) dan sirih hijau ( Piper Betle L . ) sebagai bahan alternatif irigasi saluran akar. e-Jurnal Pustaka Kesehat. 2014;2(3):556-562.

11. Nivianti D. Efektivitas Infus Daun Sirih Sebagai Antibakteri Streptococcus mutans Penyebab Karies Gigi. Sainmatika. 2013;10(1):7-10.

12. Utami DER, Krismayanti L, Yahdi. Pengaruh jenis sirih dan variasi konsentrasi ekstrak terhadap pertumbuhan jamur. 2015; VII. 